\title{
Country of origin association in retail and wholesale branding
}

\begin{abstract}
The purpose of this paper is to consider country of origin in terms of its association with brand heritage and its implications in fashion branding, thus providing a new perspective within the context of retail and wholesale brands. This qualitative study demonstrates how country of origin is widely used as a communicative tool by retail and wholesale brands, associated with brand heritage. However, the way country of origin is manifested and/or associated (e.g. brand name, colour etc.) varies depending on a brand's history, positioning, brand value, and the type of market sector that the retail and wholesale brands are targeting.
\end{abstract}

Keywords - Country of origin, Branding, Retail brands, Wholesale brands, Fashion

\section{Introduction}

Various researchers have shown interest in the concept of brand origin and country of origin (COO) branding (e.g. Johansson et al., 1985; Schooler, 1965; Thakor \& Kohli, 1996; Phau \& Prendergast, 2000). The recent interest in this field can to some extent be attributed to the fact that products communicate complex country of origin information, which has had a significant impact on the $\mathrm{COO}$ effect on product image and brand image in consumer purchasing evaluation (Lim \& O'Cass, 2006; Samiee et al., 2005). In general, country of origin is often associated with its legal definition, which is where the product is manufactured, often characterised as "Made in [...]" (Miranda and Parkvithee, 2013; Rashid 
et al., 2016). Furthermore, country of origin is sometimes associated with the home country of a brand.

According to the existing literature, the home country of the brand can be linked to the location of the headquarters of the company that owns and markets the brand, or as a place where the product or the brand was first established (Balabanis \& Diamantopoulos, 2008; Dikcius \& Stankevicienè, 2010; Jeong et al., 2012; Miranda \& Parkvithee, 2013). Hence, the home country of the brand is often linked with a brand's heritage and history (Rashid et al., 2016), regardless of where the product is manufactured (Samiee et al., 2005; Balabanis and Diamantopoulos, 2011). In addition, a number of scholars contend that the reputation of the home country (e.g. with regards to social, environmental or political factors or workmanship) (e.g. Chen et al., 2011; Insch and McBride, 1998, 2004; Jiménez \& Martin, 2012; Li \& Wyer, 1994; Lim \& O’ Cass, 2001; Michaelis et al., 2008; Verlegh \& Steenkamp, 1999) has a substantial impact of the consumers' views and reaction to COO or country of brand origin. This is further influenced by consumer characteristics such as demographic and cultural values (e.g. ethnocentrism and patriotism) (Kaynak \& Kara, 2002; Lee et al., 2013; Lin \& Chen, 2006; Pecotich \& Rosenthal, 2001; Schooler \& Sanoo, 1969; Shimp \& Sharma, 1987; Wong et al., 2008).

Previous studies have identified a range of marketing techniques to promote country of brand origin; for instance, Thakor \& Kohli (1996) and Usunier (2011) considered brand origin with reference to communication, and the way brand name is used as a marketing tool to convey country of origin. Buckley (2011) investigated cultural perspectives regarding the notion of brand country of origin. Chao et al. (2005) and Usunier (2011) considered foreign branding that can make the origin of the brand fuzzy and complex. 
At present, the literature on COO branding primarily deals with purchasing issues from the consumer perspective (Lee et al., 2013; Lin and Chen, 2006; Pecotich and Rosenthal, 2001; Schooler and Sanoo, 1969; Wong et al., 2008). Adding to the literature on the issue of the COO effect on consumer purchasing, Samiee et al. (2005) suggested that the COO effect has been inflated, to which Usunier (2006) agreed, suggesting that the concept of the COO effect has become irrelevant, particularly in the UK market, as very few customers care about where the product is manufactured (see Rashid et al., 2016). Contradicting these studies, the study by Magnusson et al. (2011) found that brand origin strongly affects brand attitudes. However, organisational and industry-related issues - particularly from fashion industry perspectives, where the differences between retail and wholesale brands have blurred - are limited in comparison (see Davies, 1992; McColl \& Moore, 2011, 2014). Moreover, consumer and purchasing-related issues cannot be applied to organizational and industry-related issues, particularly within the fashion industry, because the fashion industry specialists cannot apply emotional and culture characteristics when making strategic decisions, such as whether to reshore manufacturing back to the UK, on the basis that the UK lost the key manufacturing skills with the rise in the living standard (e.g. EY, 2015). In other words, the education of young people has been redirected towards the service sector (EY, 2015. P.05). Consequently, the objectives of this paper are 1) to review the existing COO branding literature with particular emphasis on evaluating $\mathrm{COO}$ associations from the consumer perspective, and 2) analyse the industry's perception on the influence $\mathrm{COO}$ has on the marketing activities of retail and wholesale brands.

By offering fresh perspectives on how country of origin is important to a brand, that is, how it creates emotional values associated with heritage and history and, thus, influences marketing activities that are conveyed in variety of ways from industry perspectives, the paper 
contributes to the promotional activities of $\mathrm{COO}$ in a specific fashion marketing and branding context. However, these findings are not limited to marketing strategies only as there will also be significant contribution towards management implications as well to how products are promoted and distributed in different retail settings and the market.

The paper is split into the following six sections: Section 1 contains an outline of the study and introduces the gaps in the existing literature. This is followed by an explanation of the objectives of the study. Section 2 analyses the current literature on COO branding. Furthermore, this section offers a detailed discussion of various marketing strategies, drawing on both consumer and industry standpoints. Section 3 considers branding with specific reference to retail and wholesale brands. Section 4 outlines the research methodology. Section 5 sets out the research findings from the viewpoint of using $\mathrm{COO}$ as a branding tool. This is done by means of a thematic template analysis approach, drawing meaning from qualitative in-depth interviews with the key industry informants. Section 6 contains an explanation of $\mathrm{COO}$ branding in the retail and wholesale branding context and evaluates the theoretical contribution of $\mathrm{COO}$ with reference to retail marketing and branding.

\section{Literature review: Country of origin branding}

Numerous authors have examined country of origin in different product categories and markets (e.g. Fetscherin \& Toncar, 2010; Godey et al., 2012; Magnusson et al., 2011; Rosenbloom \& Haefner, 2009; Phau \& Prendergast, 2000; Phau et al., 2008).

In general, country of origin is often associated with the place of manufacture. However, due to globalization, significant - and increasing - competition from imported goods and brands, 
and global sourcing, the notion of country of origin has become unclear, with country of manufacture no longer fully corresponding to the brand's home country. Consequently, various authors have examined the relevance of brand origin in different product categories. For example, Samiee et al. (2005) examined brand origin and suggested that brand origin recognition is largely based on consumers' association with the brand name as well as with the languages that suggest country of origin, regardless of where the brand was manufactured. Essoussi et al. (2011) suggested that brand origin might have the ability to impact brand image and brand equity. This is partly because brand origin is a strong and stable brand association that exists and remains in consumers' long-term memory (Keller, 1993), especially as consumers frequently recognize brand origin (Lim \& O'Cass, 2006). In addition, Samiee et al. (2005) suggested that consumers have limited knowledge about the accuracy of a brand's actual place of origin. In the same vein, Leclerc et al. (1994) examined the of the use of foreign branding to boost market position and the accentuation of country image to evoke positive association as well as the effect it has on perceptions and attitudes, and found that using spellings or pronunciation evoked using a foreign language is a sufficient single cue that affects consumer memory and hedonic perceptions of country of origin.

Based on the literature review above, a proposition has been postulated:

P1. Country of origin is important based on the perception of and association with a country and, thus, impacts a brand image.

Following brand origin association theory, various authors have examined the ways through which brand origin is conveyed through a promotional strategy, such as brand name (e.g. 
Samiee et al., 2005; Kim \& O’Cass, 2006; Leclerc et al., 1994; Magnusson et al., 2011) as well as visual cues and celebrity endorsements (Usunier, 2011). For example, Nespresso is “de-Swissified” by George Clooney, L'Ore'al is "un-Frenched” by Claudia Schiffer (p. 488). Moreover, some authors (e.g. Chao et al., 2005; Usunier, 2011) have highlighted how branding techniques are making it difficult to identify the accurate origin of a brand. However, no research to date has examined country of brand origin in the context of fashion retail and wholesale brands from an industry perspective.

P2. Country of brand origin can be communicated through a brand name.

P3. Country of brand origin can be triggered by other promotional activities.

\section{Branding: Retail and wholesale brand context}

In broad terms, branding can be described as a strategy aimed at creating recognition and at differentiating a product from its competitors (Aaker, 1991; Doyle \& Stern, 2006; Kotler \& Armstrong, 2010) using distinctive approaches, such as name, term, sign, symbol, design and other features, that reflect the brand's values, mission and vision. Zatepilina-Monacell (2014) argues that a brand is not only about the logo design, but also about the story of the product told by companies and their consumers. Furthermore, according to Dillon (2011) and Jackson and Shaw (2008), the concept of branding in the fashion industry is especially important as it adds an emotional and symbolic connotation to the brand's identity, which adds uniqueness and a point of differentiation to what can intrinsically be a fairly generic product, which consumers subsequently associate with in order to fulfil their needs and desires to achieve a particular status or identity (Brïdson and Evans, 2004; Birtwistle and Freathy, 1998; Keller, 1993; Nia and Zaichkowsky, 2000). 
Consequently, fashion retail brands and wholesale brands are compelled to create branding strategies that are designed to communicate individuality to the targeted audience (Birtwistle and Freathy, 1998), increasing consumer trust (Keller, 1993) and loyalty, and thereby ensuring retail success (Birtwistle et al., 1999). For example, a fashion retail brand may portray its principles by means of physical symbols and the employment of representative colours, in the manner that Victoria's Secret has done fruitfully with styles, patterns and colours that highlight allure and sexiness, employing soft pink to enhance a feminine setting (Chang et al., 2004). Also, a retail brand may position itself to exceed the innate functional value of its products by providing innovative style and design, improvements in product quality, or through store ambience, staffing levels and the provision of skilled and knowledgeable staff (Birtwistle and Freathy, 1998). Equally, a wholesale brand may position itself to maximise its social, symbolic and emotional value by offering a set of promises to consumers through a strong brand name and high product quality.

As a result, the general concept of branding in a retail context and, in particular, specifying the differences between wholesale and retail brands, has been extensively researched (Ailawadi \& Keller, 2004; Davies, 1992; Glynn et al., 2012; Martenson, 2007). For instance, Davies (1992) considered the concept of retailers as brands in their own right, suggesting that this includes branding as both a product and a process branding. "Product" within retail branding is described as a tangible attribute solely manufactured, designed and sold in an exclusive retail store (Davies, 1992). On the other hand, "process" is about the service that customers experience as they walk into the store, e.g. customer service, staff, fixtures, warranty and other elements (Davies, 1992). 
Moreover, researchers have also shown increasing interest towards the concept of wholesale branding, (Chimhundu et al. 2010; Goworek \& McGoldrick, 2015; Keiser \& Garner, 2012; Salmon, 2013) related to branded products. The branded products are created with a unique label owned by the manufacturers or suppliers (Chimhundu et al., 2010) and distributed in a series of third party wholesale distribution outlets, such as department stores, independent stores and concessions (Kumar, 1997; Salmon, 2013). In addition, Dicken (2015) points out that some wholesale brands once had ownership of manufacturing facilities (e.g. Hugo Boss, Ralph Lauren, Barbour, etc.), but due to high production costs, the majority now use offshore subcontractors and are entirely design or marketing focused, running a more overtly retailoriented business. For example, fashion wholesale brands (e.g. Burberry, Musto and Henri Lloyd) who initially established their brand by using a British identity and by manufacturing in the UK, have now moved most of their production overseas in order to attain lower labour cost advantages, and have thus become more retail-oriented businesses, owning dedicated stores as well as distribution through third party stores and channels (Dicken, 2015; Goworek \& McGoldrick, 2015; McGoldrick, 2002).

Despite increasing involvement in globalisation and offshoring, the British associations and connotations for brands that were once manufacturers in their own right continue to play a key part in their brand values and branding strategies. In other words, there are some wholesale brands for whom heritage is an important part of their brand identity and brand message (see also Rashid et al., 2016). Thus, country of origin becomes an important part of the brand heritage story.

P4. Country of origin is important for wholesale brands as it is linked to heritage and history. 
Similarly, changes have occurred in branding strategies by retail brands, becoming more like wholesale brands and/or manufacturer brands (Leingpibul et al., 2013; McGoldrick, 2002). For instance, many British retailers (e.g. Topshop, River Island and Dorothy Perkins), who in the past would have sold merchandise in their own exclusive retail stores, are now also using a wholesale strategy, selling their retail branded products not only through exclusive retail stores, but also through other third party distributors (e.g. department stores, online retailers and concessions).

Based on the literature above, a set of research propositions has been formulated and incorporated within the relevant literature, emerging from the field of country of origin and branding, identifying the gap concerning how country of origin influences the marketing activities of the UK fashion industry, compassing retail and wholesale brands, under the consideration that there is an increased growth in globalisation and in UK-based fashion brands trying to create global recognition. To address this gap, a set of questions were formulated to be asked in the semi-structured interviews used in the research;

1. Would you refer to your brand as a retail or wholesale brand or as a manufacturer?

2. Do you use any of the COO constructs (country of parts, country of design, country of manufacture and/or country of manufacture) in your marketing activities? If so, which one and why?

3. Could you think of other ways through which branded products or services emphasize country of origin?

4. What implications does COO have on your brand message and how does it impact the brand image?

In summary, the section above presents the existing literature on country of origin and branding, emphasising the gap in the context of retail and wholesale brands, with specific 
reference to the UK fashion industry. Consequently, this study adds knowledge regarding the impact of country of origin on marketing activities in the UK fashion industry. Furthermore, the study also contributes to the knowledge of how the structure of retail and wholesale brands has become obscured in the UK fashion industry, influenced by COO being integrated (or not) into marketing activities. Thus, the paper provides an integrated framework by incorporating the fashion industry's perception and associations and how country of origin is used as a branding activity in fashion retail and wholesale brands. The next section focuses on underpinning the philosophy and methods that have been employed to conduct this research.

\section{Methodology}

This qualitative study employed an interpretive approach to gain an in-depth understanding of how country of origin is branded in a fashion retail and wholesale brand setting. Thus, the ontological position, which underpins the design of this study, is subjective in nature, seeking to develop an understanding of how $\mathrm{COO}$ influences the marketing activities of fashion retail and wholesale brands.

To carry out the research, the study initially intended to interview representatives of fashion retail and wholesale brands, as differentiated by Davies (1992). Consequently, the sampling process started by using a key informant approach to respondent selection (Barnes and LeaGreenwood, 2006), whereby respondents were chosen using a non-probability, judgement sampling approach, due to their knowledge of and influence on branding and manufacturing strategies in the UK. When the actual process of interviewing started with the first few key informants from the UK fashion industry, it became apparent that it was difficult to truly find distinct retail and distinct wholesale brands. In accordance with this, an approach was 
adopted whereby the study looked at a range of fashion brands from retailers through to wholesale brands, which included different hybrid types of brands in between, such as design-led brands and multi-channel retailers, all of whom (apart from one) were using both retail and wholesale brand strategies.

To strengthen the findings, the researcher then took the approach to look at the industry as a whole as it was difficult to fit retailers into the categories of retail and wholesale brands. As a consequence, key informants were also selected from fashion businesses, including garment suppliers, component suppliers and textile and fashion consultancy companies.

The study comprised 16 semi-structured face-to-face interviews with key informants representing $14 \mathrm{UK}$ fashion brands and organisations (see table 1), all of whom incorporate $\mathrm{COO}$ as part of their overall branding strategy. This included retailers and manufacturers as well as other organisations such as textile and fashion consultancy companies. The key informants included executives, managers, assistant buyers, heads of department, CEOs and more (see table 1). The diversity of key informants provided triangulated perspectives with data on the importance of country of origin and its use in branding tools, and also highlighted divergences and convergences (Dion and Mazzaolovo, 2016; Speziale et al., 2011).

With no existing database on experts within fashion retail and wholesale brands to provide a sampling frame, a list of respondents was devised using a variety of sources. The key informants from retailers, wholesale brands and other fashion industries were identified via LinkedIn (2017), the Association of Suppliers to the British Clothing Industry (ASBCI) (2014), the fashion network events (2015), and personal contacts. These events were considered beneficial for this study as the key speakers were representatives from the fashion 
industry, incorporating retail and wholesale brands, and were invited to the event to discuss the importance of "Making it in the UK".

All the key informants from retailers and manufacturers, as well as textile and fashion consultancies, were approached via the three-stage process of formal letter, email and phone call. However, where it was possible to identify the name and email of the person responsible for manufacturing in the fashion companies (e.g. CEO or director of marketing) via personal contacts, the informants were contacted directly. In order to uphold commercial confidentiality, the participating organisations cannot be identified (Doherty, 2000).

\section{Insert Table 1 Here}

The interview questions were drawn from the existing literature focusing on branding and country of origin (Balabanis and Diamantopoulos, 2011; Godey et al., 2012; Magnusson et al., 2011; Phau and Prendergast, 2000; Usunier, 2006, 2011), considering the importance and use of different promotional strategies to convey country of origin. The interview process started with a very basic question, inquiring about the informant's role, the length of their employment, and about the company's background (Innes, 2013). The next step of the interview process was to investigate whether the companies referred to themselves as brands and if so, then what type of brand (e.g. retail or wholesale brand, manufacturer, business to business brands), as perceived by the respondent. To gain a deeper understanding on whether companies operated a retail or wholesale brand strategy, the laddering technique was adopted by probing with questions on whether companies sold their own brands in their own stores or through other stores and channels and the advantages and disadvantages thereof as well as topics concerning the use of $\mathrm{COO}$ in their branding strategies. According to Reynolds and Gutman (1988), laddering involves a series of directed probes, typified by the "Why is that important to you?" question, with the express goal of determining the association between the 
key perceptual elements across the range of attributes, consequences, and values. The reason for using the laddering technique in this qualitative interview process was because the terminology of retail and wholesale brands is no longer frequently used in the UK fashion industry, which helped in determining how retail respondents use both retail and wholesale brand strategies in the UK fashion business. The respondents were then asked what they understood by country of origin, whether they conveyed country of origin as a branding element; and if so, which one and how. Finally, questions were asked regarding the impact that country of origin association and promotion have on a brand image.

Most of the interviews were held at the respondents' offices in the UK, whilst one was conducted via Skype due to company undergoing refurbishment, and lasted between 30 and 60 minutes. The interviews were audio-recorded and transcribed. Through an inductive approach (King and Horrocks, 2010; Dion and Mazzalovo, 2016), the data were analysed thematically. Thematic analysis involves analysing data by recognising the patterns and themes systematically in order to understand the meaning (King and Horrocks, 2011).

\section{Findings}

The findings are structured using two themes, namely 1) place and nation association with COO branding and 2) colour association with $\mathrm{COO}$ branding.

\subsection{Place and nation association}

All respondents agreed that country of brand origin is considered important, that it is associated with heritage, history and emotional values, and that it reflects the brand image, as the British image is associated with quality in certain countries, such as in the Scandinavian 
region. However, the level of association and the way country of origin is promoted varies depending on a brand's history, value and mission, and positioning. The section below addresses place and national association in marketing activities influenced by the concept of COO.

It is evident from the retail respondent of company A, a representative of an affordable fast fashion retailer, that country of origin of a brand, also referred to as country of brand origin, is manifested through the use of locational association in a sub-brand name. It was further explained that the association with the sub-brand name was because the company has undergone several changes over the years, whereby the company is trying to target a market that constantly demands new and fresh design. Thereby, associating the sub-brand name with the location where the brand was first established and which it was originally named after allows the company to associate with brand history and has also created opportunities for the target market the company was previously targeting. Meanwhile, a wholesale senior retail respondent from company $\mathrm{G}$, a representative of an outdoor clothing manufacturer, revealed that the entire brand has strong connotations to being a British brand; thus, place association, which is the British image, is conveyed through taglines and the Union Jack, however the company also takes pride in conveying brand history by embedding the location in which the company was first established. Furthermore, this is one of the most expensive sub-brands manufactured by the company due to its heritage history, strong British associations, including manufacturing some products in the UK, and finally, the use of material in the product line that is manufactured specifically by the company:

"The $\mathrm{COO}$ of our brand is associated with heritage history, which is promoted through our sub-brand name. For example, our ladies-wear sub-brands are named 
after the original company name, before the company re-branded with its new name, and our men's wear sub-brand is named after the location where our store was first established in London" (Buyer, Company A).

In addition to this, senior respondents from companies $B$ and $\mathrm{G}$, respectively a representative of a retail brand that focuses on selling only its own brands in clothing category and a representative of a wholesale British lifestyle brand that also operates a retail brand strategy in outlets, have pointed out how important British values are for brands that have been established in the market for years. Therefore, such companies take pride in conveying this as part of their brand message. However, a senior respondent from company G, a representative of a British lifestyle brand, also explains that the royal warrant, given to them for being leaders in outdoor clothing outfitters, also represents the Britishness of the brand. Meanwhile, the respondent from company B has highlighted the emphasis on heritage history in store merchandise by creating a vintage British association through the use of a large wooden table in retail stores, and an Italian association through the use of a decorative little Vespa moped. Thus, it is evident that British association is important for both retail and wholesale brands, and has an impact on the marketing actives of both retail and wholesale brands. However, the way they promote can vary:

"So, we have been talking about celebrating 125 years, and that is our heritage and even our brand message. So, our brand message is driven by our 125 years of establishment and customers' trust" (Head of Department, Company B). 
“[...] And then, on the top of that, we've got the royal warrants, which were from the Queen, the Duke - strongly associating this with the Britishness" (Marketing Director, Company G).

However, the respondent from company $\mathrm{K}$, a representative of a newly established wholesale brand originally recognised as a component supplier, pointed out how important country of origin is to their brand, particularly with reference to technical aspects that are taking place in UK mills. Therefore, the company takes pride in promoting this on their website, creating awareness about the British association particularly on their webpage. This goes in hand with the respondent company $\mathrm{J}$, who are also known as component suppliers. Respondent from company $\mathrm{K}$ have pointed out that they are also a supplier brand and sell their haberdashery products in a range of UK department stores, and that the recognition of being a British brand is important to them as it contains emotional values:

"For us, British association is important because it links to the technical aspects that are taking place in the UK. So, on our website we actually talk about British mills and the technical input" (Non-Executive Director, Company K).

Moreover, a senior representative from the British premium brand company $\mathrm{H}$, which is a leader in outdoor clothing, highlighted the importance of using foreign brand names for their company, suggesting that in some parts of Europe (e.g. Germany), the British image has been associated with being vintage but also boring, as British culture has been considered to be less active and adventurous. Thus, to make the brand appealing to the European market, the company is using a foreign brand name, thus making associations with a specific country 
image. Consequently, it is evident that country image association can influence marketing activities, especially when targeting a specific market. This was further agreed to by a senior respondent from company $\mathrm{K}$, a representative of a well-known component supplier historically known for manufacturing components in the UK, and a senior respondent from company $\mathrm{N}$, a representative of a company that conducts research and supports other fashion and textile companies in the UK. They stated that $\mathrm{COO}$ in a marketing activity is particularly important for niche brands that target a specific market, but that it also creates emotional and social associations. However, in terms of company $\mathrm{H}$, the company uses a foreign brand name although it originated in the UK; therefore, the design functions continue to take place in the UK. For example:

“[...] some European countries still consider Britain as old fashioned and boring - for old people" (Creative Art Director, Company H).

The senior respondent from company $\mathrm{H}$ reiterates that the relevance of communicating country of origin (the brand being British) varies according to the type of product, country image and place associations. Furthermore, similar views were put forward by the CEO of company E, who pointed out how they emphasised more on the brand being British when selling in Scandinavian countries, because British means quality there. However, the retail respondent from company A, a representative of an affordable fashion retailer, had different views, pointing out how the company focuses on targeting a wider international market and that, if they were to use the direct marketing approach of communicating British association, it may seem as though the brand is tailored simply for the British market. Therefore, to create global recognition, company A does not promote country of origin in its marketing activities. These views are evidence of how the extent to which country of origin influences marketing 
activities is dependent upon brand positioning and the type of market the company is targeting, which is also affected by the stereotypical perception a market has of a specific country image. For example:

"[...] it depends on where you are standing in the world. So, if you are standing in Japan, I would call the brand British because the Japanese market thinks British is a really good thing" (Creative Art Director, Company H).

In summary, section 5.1 has highlighted how different perceptions of the same country can occur in fashion branding, depending on brand positioning and the type of market and country the brand is targeting. The next section will discuss colour associated with COO in fashion retail and wholesale branding.

\subsection{Colour association}

All respondents from wholesale brands indicated that colour can have strong associations with culture and a country and, as a result, a brand can communicate heritage and history through the use of specific colours on logos, prints and patterns as well as other marketing tools. For example:

"[...] but this can also be seen through the colour we use on our brand name and overall brand theme, associating with the rich history drawn from the countryside and the history (Marketing Director, Company G). 
Additionally, retail respondents of companies C, E, and G all of which could traditionally be considered as representatives of wholesale brands but which also now operates a retail brand strategy, have indicated how colour has a strong association with country and culture. They also asserted that, to keep business ideas fresh and to attract a wider international market, companies can make changes to colour association in a brand message and also merchandise in order to maintain an association to a specific country image, or to move away from a country association. For example:

“[...] we are going for a new clear aesthetic style and moving away from the grey vintage wash, and other vintage elements, which includes anything grungy" (Designer, Company C).

On the other hand, a retail respondent of company A, which is well known on the UK high street for its style and affordable fashion, highlighted how the use of colour in branding strategies and the choice of product merchandise has no connotation to a specific country image. Instead, the colour association is strongly influenced by their target market (e.g. young and chic) and other international fashion destinations. For example:

“As a fashion business, most of our colour choices are inspired prominently by the fashion shows, not just London, but we would look worldwide. We would look at shows in Milan, London, and then because we are a very youth-focused brand, we are also very inspired by the street styles, from New York to Copenhagen" (Buyer, Company A). 
A wholesale respondent from company $\mathrm{H}$, with a foreign-sounding brand name but a British brand heritage, added that their logo uses colours that associates with the British flag, but the colours they actually use on their product merchandise vary, as different countries and cultures have different preferences regarding design and colour. This was said with particular reference to German culture having preferences for two colours, rather than the three on the actual product, as the German market has a preference for simple products, whilst the UK market has a preference for more colours. Furthermore, the respondent's view was that France, Poland, and even Nordic countries have similar preferences and views with regards to country perception and colour preferences. However, this was in contrast to the wholesale respondent's view from company E, who previously pointed out that Scandinavians consider British to be associated with quality (see section 5.1). For example:

"In the Nordic countries, they like to shout out about where the product is designed or the country where the brand comes from, so we have to make sure that to sell well in our chosen market and that we design close to them. In terms of the use of colour, our logo represents British heritage, but the use of colour on the product merchandise varies. For example, Germany doesn't like three colours in one product. So, if you have one colour on the top body, and the different colour on the lower part and then third colour on the zip, they freak out completely (Creative Art Director, Company $\mathrm{H})$.

To sum up, section 5 highlighted how country of origin influences the marketing activities of retail and wholesale brands, induced by a range of factors such as country image, target market, brand history and brand positioning. This section also illustrated a range of manners through which country of origin is promoted, with the key promotional activity being the 
brand name of sub-brands, to provide traditional customers with the choice to associate with the heritage history of the brand; the second is colour association, which reflects the emotional values a brand has in connection with its brand history and heritage. The next section (6) will present a discussion and conclude the entire paper, in addition to giving the limitations and suggesting avenues for further research.

\section{Discussion and conclusion}

The objectives of this paper were: First, to review the existing COO branding literature that has previously been documented mainly from the consumer perspective; and second, to analyse the fashion industry's perception of the influence $\mathrm{COO}$ has on the marketing activities of retail and wholesale brands and, consequently, how the fashion industry uses $\mathrm{COO}$ as a branding tool. This paper informs on how country of origin is important for industry experts, due to the emotional values that are attached to the heritage history of a brand, and how $\mathrm{COO}$ influences the marketing activities of retail and wholesale brands, in the context where the differences between retail and wholesale brands have blurred extensively over the years.

The findings of this paper make a contribution towards the literature of fashion branding and positioning, and the study reveals that the UK fashion industry perceives country of origin to be important, relating to emotional value, heritage and history, and how $\mathrm{COO}$ influences the marketing activities of the UK fashion industry. This is increasingly dependent on the type of market a brand is targeting, the perception of the country image, brand positioning, expertise, the strategic business plan and the brand's value and mission. Consequently, the study also adds knowledge to how the UK fashion industry uses COO as a branding tool. 
The existing literature (e.g. Dinnie, 2015; Samiee et al., 2005; Thakor and Kohli, 1996) highlights how a brand's heritage is bound up with brand origin, and that it is difficult to conceive a heritage without an accompanying image of a particular place. Contributing to this literature stream, this study revealed that there are many ways through which the origin of a brand can be associated with heritage, and subsequently communicated. For example, country, location and history can be manifested in a brand name or sub-brand name, logo or website in order to increase the brand equity by creating emotional and symbolic connotations to the brand identity in the minds of customers (see also Dillon, 2011; Jackson and Shaw, 2008). However, the method an organisation applies to communicate any aspect of country of origin depends on the brand's target market, the brand's mission and vision, and what the brand aims to be perceived as; examples include the Blue Harbour collection at $\mathrm{M} \& \mathrm{~S}$, which focuses on young, sports-oriented men, and the use of Harris Tweed in the M\&S collection, which creates an emotional association with British values. On the other hand, fashion brands with a leading history particularly promote their British values across a range of channels, including websites, an example being, Musto, a leader in performance outdoor clothing. In the same vein, other fashion companies, such as suppliers, also take pride in communicating their history (e.g. Karpelle is the leading UK clothing manufacturing company, and the origins are based manufacturing within its own UK factories), allowing companies to enhance their brand positioning and brand image. This adds knowledge to the literature of country of origin and branding, pointing out how country of origin of a brand is important to all types of brands and companies and can be communicated variety of ways, creating an impact on brands identity. It can also perform as a way of creating brand loyalty and, thus, equity. 
The results indicate that country of origin of a brand is both important and linked to heritage and that country of origin can be communicated through the use of specific colours. For example, green is associated with Scottish heritage and countryside and blue with water sports associates with a brand's value, mission and vision. On the other hand, retail brands that target the younger market may use colour that appeals less to a brand's history and more to market choice, like Topshop. This resonates with Labrecque and Milne (2011) and Labrecque et al. (2013), who explain that the use of colour is an integral aspect of marketing and corporate communication (see Aslam, 2006) that aids in constructing a visual brand identity intended to target a specific market and help maintain the brand heritage. Therefore, this represents a contribution to the literature of branding, marketing communication and country of origin, illustrating how the association with colour reflects not only a brand's history and values, but also its identity.

Furthermore, Leclerc et al. (1994) have previously identified how a foreign brand name allows companies to boost market position in an attempt to evoke positive association. Going in hand with this, this study indeed found that some fashion companies are using foreign brand names in their branding strategies; however, in the same vein, the companies have an association with their brand's heritage through the colour association in a logo or even using store merchandise or store displays (e.g. the Union Jack displayed in a Superdry store), and thus, this contributes to the literature on branding and marketing, highlighting the relevance of a brand's heritage whilst improving brand positioning.

In conclusion, country of origin is important and linked with heritage, history and emotional values. However, the importance of promoting country of origin and/or brand origin depends 
on the preferences and perceptions of the receivers in different countries, the expertise of the brand, the brand positioning and its value and mission. For example, a retailer that is a brand in its own right (see Davies, 1992) may not consider promoting brand origin to make it more appealing to the younger market and the international market. On the other hand, a wholesale brand may promote country of origin and brand origin because of their heritage history and the preferences of the countries they are targeting. Thus, the paper contributes towards branding and promotion literature and also provides an insight for the industry in terms of how country of origin is associated with heritage and is used as a promotional tool.

\subsection{Managerial Implications}

Along with theoretical contribution, this study provides insight regarding how fashion companies associate with $\mathrm{COO}$ in their branding strategies, reflected by emotional and symbolic values, and also how $\mathrm{COO}$ influences the marketing activities of both retail and wholesale brands which evoke brand positioning and brand identity. An example is the place and nation association with an actual brand name or with a sub-brand name as well as the use of colour association, such as the use of tartan or green to associate with Scottish heritage, or the use of a clear aesthetic to attract a wider European market. Finally, it has emerged that the influence $\mathrm{COO}$ has on marketing activities largely depends on the brand positioning, which is often influenced by the type of market a brand is targeting; thus, understanding and knowledge about customer demand is essential. 


\subsection{Limitations}

This study has made a contribution to the literature of branding and $\mathrm{COO}$, regarding how different fashion companies associate with $\mathrm{COO}$ in their marketing activities in the context of retail and wholesale brands, with specific reference to the UK fashion industry. However, the study has identified several challenges and limitations in doing this research. First, the process of identifying the key informants of the UK fashion industry was difficult as fashion companies provide limited databases on the internet. Second, the actual process was timeconsuming as travelling to different cities and towns was required to reach the key informants in order to gain rich data. Furthermore, although the interview process lasted 30 to 60 minutes, transcribing the actual interviews took longer.

\subsection{Future research direction}

First of all, based on the findings, it is confirmed that fashion brands cannot be split into the categories of retail and wholesale brands as the differences between the two have become blurred. However, retailers can be categorised into individual segmentations affiliated with a brand or company's expertise or identity.

Furthermore, this study has identified how country of origin can impacts retail image, product image or country image, depending on brand expertise, brand positioning and strategic longterm plan. This opens up the avenue for future studies, such as investigating country of origin (different dimensions) with specific reference to online retailing, covering both industry and consumer perspectives, as country of manufacturing cannot be identified in an e-tail strategy. In addition, some issues can also be associated with COP, COD and COB (e.g. colour, design 
and quality). Furthermore, there is also space for further research in considering how luxury brands implement $\mathrm{COO}$ in their advertising (heritage, culture, etc.) and this can be examined for different product categories.

\section{References}

Aaker, D.A. (1991). Managing Brand Equity. New York: Simon and Schuster.

Ailawadi, K.L. and Keller, K.L. (2004). Understanding retail branding: Conceptual insights and research priorities. Journal of Retailing, 80(4), pp.331 - 342.

Aslam, M.M. (2006). Are You Selling the Right Colour? A Cross-cultural Review of Colour as a Marketing Cue. Journal of Marketing Communications, 12(1), pp.15-30.

Balabanis, G. and Diamantopoulos, A. (2008). Brand Origin Identification by Consumers: A Classification Perspective. Journal of International Marketing, 16(1), pp.39 -71.

Barnes, L. and Greenwood, L.G. (2006). Fast fashioning the supply chain: shaping the research agenda. Journal of Fashion Marketing and Management, 10(3), pp.259 -271.

Birtwistle, G. and Freathy, P. (1998). More than just a name above the shop: a comparison of the branding strategies of two UK fashion retailers. International Journal of Retail and Distribution Management, 26(8), pp.318 - 323.

Birtwistle, G., Clarke, I. and Freathy, P. (1999). Store image in the UK fashion sector: consumer versus retailer perceptions. The International Review of Retail, Distribution and Consumer Research, 9(1), pp.1-16.

Brïdson, K. and Evans, J. (2004). The secret to a fashion advantage is brand orientation. International Journal of Retail and Distribution Management, 32(8), pp.403 - 411.

Buckley, C. (2011). References to the past- the role of heritage and cultural values in fashion 
branding. In 13th Annual Conference for the International Foundation of Fashion Technology Institutes: Fashion between heritage and innovation luxury, 13-14 April 2011, Paris, France. Paris.

Chao, P., Wiihrer, G. and Werani, T. (2005). Celebrity and foreign brand name as moderators of country-of-origin effects. International Journal of Advertising, 24(2), pp.173 - 192.

Chen, H.L. (2011). Effects of Country-of-Origin, Consumer Patriotism, and Values on Brand Strength: A Multi-attribute Setting. International Proceedings of Economics Development and Research, 3, pp.267 - 272.

Chimhundu, R., Hamlin, R. and Mcneill, L. (2010). Impact of Manufacturer Brand Innovation on Retailer Brands. International Journal of Business and Management, 5(9), pp. 10 - 18.

Davies, G. (1992). The Two Ways in Which Retailers Can Be Brands. International Journal of Retail and Distribution Management, 20(2), pp 405 - 421.

Dicken, P. (2015). Global Shift: Mapping the Changing Contours of the World Economy, U.S.A: The Guildford Press.

Dikčius, V. and Stankevičienè, G. (2010). Perception of country of brand origin and country of product manufacturing among Lithuanians and emigrants from Lithuania. Organization and Markets in Emerging Economies, 1(2), pp.108 -123.

Dinnie, K. (2016). Nation Branding: concepts, issues, practise. London and New York: Routledge

Dion, D. and Mazzalovo, G. (2016). Reviving sleeping beauty brands by rearticulating brand heritage. Journal of Business Research, 69 (12), pp. 5894 - 5900.

Dillon, S. (2011). The Fundamentals of Fashion Management, New York, USA: A\&C Black.

Doherty, A.M. (2000). Factors Influencing International Retailers' Market Entry Mode Strategy: Qualitative Evidence from the UK Fashion Sector. Journal of Marketing Management, 16(1-3), pp.223- 245 . 
Doyle, P. and Stern, P. (2006). Marketing Management and Strategy. Edinburg, UK: Financial Times Prentice Hall.

EY Report (2015). Reshoring manufacuring - time to seize the opportunity: the economic opportunity for the UK to reshore and the implications for Government and businesses.

Glynn, M.S., Brodie, R.J. and Motion, J. (2012). The benefits of manufacturer brands to retailers. European Journal of Marketing, 46(9), pp.1127 -1149.

Godey, B., Pederzoli, D., Aiello. G., Donvito, R., Chan, P., Oh, H., Singh, R., Skorobogatykh., Tsuchiya.J., Weitz, B. (2012). Brand and country-of-origin effect on consumers' decision to purchase luxury products. Journal of Business Research, 65(10), pp.1461-1470.

Goworek, H. and McGoldrick, P. (2015). Retail Marketing Management: Principles and Practice, UK. Harlow, UK: Pearson.

Insch, G.S. and McBride, J.B. (1998). Decomposing the country-of-origin construct: An empirical test of country do design, country of parts and country of assembly. Journal of International Consumer Marketing, 10(4), p.69.

Insch, G.S. and McBride, J.B. (2004). The impact of country-of-origin cues on consumer perceptions of product quality: A binational test of the decomposed country-of-origin construct. Journal of Business Research, 57(3), pp.256 - 265.

Jackson, T. and Shaw, D. (2008). Mastering Fashion Marketing, Palgrave Macmillan: London, UK.

Jeong, S.W., Stoel, L. and Chung, J.E. (2012). Impacts of store type importance and country of origin: Exploring the case of dietary supplements in the Chinese market. International Journal of Retail and Distribution Management, 40(6), pp.471 - 487.

Jiménez, N. and Martín, S.S. (2012). Emerging Markets Commerce: The Role of Country-of-Origin and Animosity in Purchase Intention. International Journal of Business and Management, 7(17), p.34. 
Johansson, J.K. and Nebenzahl, I.D. (1986). Multinational Production: Effect on Brand Value. Journal of International Business Studies, 17(3), pp.101 - 126.

Kavaratzis, M. and Ashworth, G. (2008). Place marketing: how did we get here and where are we going? Journal of Place Management and Development, 1(2), pp.150 - 165.

Kavaratzis, M., Warnaby, G. and Ashworth, G. (2014). Rethinking Place Branding: Comprehensive Brand Development for Cities and Regions. Switzerland: Springer.

Kaynak, E. and Kara, A. (2002). Consumer perceptions of foreign products: An analysis of productcountry images and ethnocentrism. European Journal of Marketing, 36(7/8), pp.928 - 949.

Keiser, S. and Garner, M. (2012). Beyond Design: The Synergy of Apparel Product Development. New York, USA: Bloomsbury publication.

Keller, K. (1993). Conceptualizing, measuring, and managing customer-based brand equity. The Journal of Marketing, 57(1), pp.1 - 22.

King, N. and Horrocks, C. (2010). Interviews in Qualitative Research. London, UK: SAGE Publications.

Kotler, P. and Armstrong, G. (2010). Principles of Marketing, Boston, USA: Pearson.

Kumar, N. (1997) The revolution in retailing: from market driven to market driving. Long Range Planning, 30(6), pp.830 - 835.

Labrecque, L.I. and Milne, G.R. (2011). Exciting red and competent blue: the importance of color In marketing. Journal of the Academy of Marketing Science, 40(5), pp.711-727.

Labrecque, L.I., Patrick, V.M. and Milne, G.R. (2013). The Marketers' Prismatic Palette: A Review of Color Research and Future Directions. Psychology and Marketing, 30(2), pp.187 - 202.

Lee, W.J., Phau, I., and Roy, R. (2013). “ Bonds ” or “Calvin Klein ” Consumer ethnocentric and brand country origin effects towards men's underwear. Journal of Fashion Marketing and 
Management, Vol. 17 No.1, pp. 65-84.

Leingpibul, T., Allen Broyles, S. and Kohli, C. (2013). The comparative influence of manufacturer and retailer brands on customers' purchase behavior. Journal of Product and Brand Management, 22(3), pp.208 - 217.

Li, G., Li, G. and Kambele, Z. (2012). Luxury fashion brand consumers in China: Perceived value, fashion lifestyle, and willingness to pay. Journal of Business Research, 65(10), pp.1516 -1522.

Li, W.K. and Wyer, R.S. (1994). The role of country of origin in product evaluations: Informational and standard-of-comparison effects. Journal of Consumer Psychology, 3(2), pp.187-212.

Lim, K. and O'Cass, A. (2001). Consumer brand classifications: an assessment of culture-of-origin versus country-of-origin. Journal of Product and Brand Management, 10(2), pp.120 -136.

Magnusson, P., Westjohn, S. A. and Zdravkovic, S. (2011). "What? I thought Samsung was Japanese": accurate or not, perceived country of origin matters. International Marketing Review, 28(5), pp.454 - 472 .

McColl, J. and Moore, C. (2011). An exploration of fashion retailer own brand strategies. Journal of Fashion Marketing and Management: An International Journal, 15(1), pp.91 - 107.

McColl, J. and Moore, C. (2013). Developing and testing a value chain for fashion retailers: activities for competitive success. The Journal of The Textile Institute, 105(2), pp.136 -149.

McGoldrick, P. (2002) Retail Marketing, London, UK: The MxGraw-Hill Companies.

Miranda, M.J. and Parkvithee, N. (2013). The influence of social class on the perceptions of country of origin. Marketing Intelligence and Planning, 31(4), pp.388 - 404.

Nia, A. and Zaichkowsky, J. L (2000). Do counterfeits devalue the ownership of luxury brands? Journal of Product and Brand Management, 9(7), pp.485 - 497.

Pecotich, A. and Rosenthal, M.J. (2001). Country of Origin, Quality, Brand and Consumer 
Ethnocentrism. Journal of Global Marketing, 15(2), p.31 - 60.

Phau, I. and Prendergast, G. (2000). Consuming luxury brands: The relevance of the "Rarity Principle." Journal of Brand Management, 8(2), pp.122 -138.

Rashid,A., Barnes, L. and Warnaby, G. (2016). Management perspectives on country of origin. Journal of Fashion Marketing and Management, 2(2), pp. 230 - 244.

Salmon, K. (2013). Going Direct: The Journey from Wholesale Brand to Direct-To-Consumer Retailer, Kurt Salmon.com: Georgia, USA.

Samiee, S., Shimp, T.A. and Sharma, S. (2005). Brand origin recognition accuracy: its antecedents and consumers' cognitive limitations. Journal of International Business Studies, 36, pp.379 397.

Schooler, R. and Sanoo, D. (1969). Consumer Perceptions of International Products: Regional vs. National Labelling. Social Science Quartely, 49(1), pp.226 - 243.

Speziale, H.S., Streubert, H.J. and Carpenter, D.R. (2011). Qualitative Research in Nursing: Advancing the Humanistic Imperative, China : Lippincott Williams and Wilkins.

Thakor, M.V. and Kohli C.S. (1996). Brand origin: conceptualization and review, Journal of Consumer Marketing, 13(3), pp. 27- 42.

Usunier, J.C. (2011). The shift from manufacturing to brand origin: suggestions for improving COO relevance. International Marketing Review, 28, pp.486-496.

Veale, R. and Quester, P. (2008). Consumer Sensory Evaluations of Wine Quality: The Respective Influence of Price and Country of Origin. Journal of Wine Economics, 3(01), pp.10 - 29.

Wong, C.Y., Polonsky, M.J. and Garma, R. (2008). The impact of consumer ethnocentrism and country of origin sub-components for high involvement products on young Chinese consumers' product assessments. Asia Pacific Journal of Marketing and Logistics, 20(4), pp.455 - 478. 
Zatepilina-Monacell, O. (2014). Communicating a Made-in-America Brand: Country-of-Origin Messaging Strategies in the US Home Furnishings Industry. Corporate Reputation Review, 17(2), pp.157 - 168 . 
Table 1: The UK fashion industry experts interviewed

\begin{tabular}{|c|c|c|c|c|}
\hline Company & Organisation Type & $\begin{array}{l}\text { Organisation } \\
\text { Target }\end{array}$ & $\begin{array}{l}\text { Interviewee } \\
\text { Position }\end{array}$ & $\begin{array}{l}\text { Origin } \\
\text { (Country } \\
\text { and City) }\end{array}$ \\
\hline Company A & $\begin{array}{l}\text { Pure own brand - Fast } \\
\text { fashion retailer }\end{array}$ & $\begin{array}{l}\text { Affordable fast } \\
\text { fashion retailer - } \\
\text { targeted to } 16-30 \text { age } \\
\text { group }\end{array}$ & 1) Buyer & UK \\
\hline Company B & $\begin{array}{l}\text { Pure own brand - } \\
\text { Quality led retailer }\end{array}$ & $\begin{array}{l}\text { Quality clothing for }+ \\
35 \text { and }+50 \text { female } \\
\text { and men }\end{array}$ & $\begin{array}{l}\text { 1) Head of } \\
\text { Department } \\
\text { 2) Buyer }\end{array}$ & UK \\
\hline Company $\mathrm{C}$ & $\begin{array}{l}\text { Premium brand - } \\
\text { Performance design } \\
\text { led retailer }\end{array}$ & $\begin{array}{l}\text { Performance clothing } \\
\text { - targeting city } \\
\text { dwellers in Europe } \\
\text { and Central America } \\
\text { (e.g. UK, Germany } \\
\text { and Canada) in } \\
\text { particular }\end{array}$ & 1) Designer & UK \\
\hline Company D & $\begin{array}{l}\text { Premium brand - } \\
\text { Performance design } \\
\text { led retailer }\end{array}$ & $\begin{array}{l}\text { Design focused } \\
\text { premium brand, } \\
\text { targeting } 35-55 \text {, with } \\
\text { core market being } \\
+45 \text {. }\end{array}$ & 1) Buyer & UK \\
\hline Company E & $\begin{array}{l}\text { Premium brand - } \\
\text { Wholesale brand and } \\
\text { Manufacturer }\end{array}$ & $\begin{array}{l}\text { Outdoor clothing for } \\
\text { water sports }\end{array}$ & 1) $\mathrm{CEO}$ & UK \\
\hline Company F & $\begin{array}{l}\text { Premium retailer and } \\
\text { own fashion brand }\end{array}$ & $\begin{array}{l}\text { Young fashion } \\
\text { retailer, } 16 \text { to } 24 \text { age } \\
\text { group }\end{array}$ & 1) Store Manager & UK \\
\hline Company G & $\begin{array}{l}\text { Premium fashion - } \\
\text { Wholesale brand and } \\
\text { Manufacturers }\end{array}$ & $\begin{array}{l}\text { Outdoor clothing for } \\
\text { wind protection and } \\
\text { more }\end{array}$ & 1) Marketing Director & UK \\
\hline Company H & $\begin{array}{l}\text { Premium Fashion - } \\
\text { Wholesale brand and } \\
\text { Manufacturer }\end{array}$ & $\begin{array}{l}\text { Outdoor clothing for } \\
\text { adventurers }\end{array}$ & $\begin{array}{l}\text { 1) Creative Art } \\
\text { Director }\end{array}$ & UK \\
\hline Company I & $\begin{array}{l}\text { Multi-channel retailer } \\
\text { (wholesaler and own } \\
\text { brand retailers) }\end{array}$ & $\begin{array}{l}\text { Plus size clothing and } \\
\text { fast fashion }\end{array}$ & $\begin{array}{ll}1) & \text { Head of } \\
& \text { Department } \\
\text { 2) } & \text { Senior Buyer } \\
\end{array}$ & UK \\
\hline Company J & Component Supplier & $\begin{array}{l}\text { Traditionally thread } \\
\text { manufacturers and } \\
\text { suppliers for premium } \\
\text { brands }\end{array}$ & $\begin{array}{l}\text { 1) President of } \\
\text { Apparel and } \\
\text { footwear }\end{array}$ & UK \\
\hline Company K & $\begin{array}{l}\text { Component supplier } \\
\text { and wholesale brand }\end{array}$ & $\begin{array}{l}\text { Outdoor clothing for } \\
\text { wind protection and } \\
\text { more (American and } \\
\text { UK brands) }\end{array}$ & $\begin{array}{l}\text { 1) Non-Executive } \\
\text { Director }\end{array}$ & UK \\
\hline Company L & $\begin{array}{l}\text { Designers and } \\
\text { manufacturer for } \\
\text { design led brands }\end{array}$ & $\begin{array}{l}\text { Premium design-led } \\
\text { brands (e.g. L.K. } \\
\text { Bennett) }\end{array}$ & $\begin{array}{l}\text { 1) } \\
\text { Senior Fabric } \\
\text { Technologist }\end{array}$ & UK \\
\hline Company M & $\begin{array}{l}\text { Textile research and } \\
\text { funding organisation }\end{array}$ & $\begin{array}{l}\text { Support companies } \\
\text { that needs funding }\end{array}$ & $\begin{array}{ll}\text { 1) } & \text { Textile } \\
& \text { researcher }\end{array}$ & UK \\
\hline Company N & $\begin{array}{l}\text { Textile research and } \\
\text { funding organisation }\end{array}$ & $\begin{array}{l}\text { Support companies } \\
\text { that needs funding }\end{array}$ & $\begin{array}{l}\text { 1) International } \\
\text { Director }\end{array}$ & UK \\
\hline
\end{tabular}

